\title{
STRIPED CATFISH (Pangasianodon hypophthalmus) (SAUVAGE, 1878) MOVEMENT AND GROWTH IN GAJAH MUNGKUR RESERVOIR, CENTRAL JAVA
}

\author{
Siti Nurul Aida ${ }^{1}$ and Agus Djoko Utomo ${ }^{1}$ \\ ${ }^{1}$ Research Institute for Inland Fisheries, Palembang \\ Received; March 20-2015 Received in revised from June 10-2015; Accepted June 12-2015 \\ e-mail:idabrppu@yahoo.com
}

\begin{abstract}
Movement is an essential mechanism by which mobile animals acquire the resources necessary for the successful completion of their life-cycles. Striped catfish (Pangasianodon hypophthalmus) contributed about 384 tonnes or approximately $40,04 \%$ to the total fish production in Gajah Mungkur reservoir. Diversion of Keduang River, one of Gajah Mungkur important inlets, could affect the movement of this fish. The objective of this research was to describe the movement patterns and to analyze growth of Pangasianodon hypophthalmus. Field works were conducted from March to December 2011 by tagging experiment of large fish with the PDS-Tags and the T Bar-Tags for the small ones. Fish samples used for the experiment were collected from fisherment catch's in Gajah Mungkur reservoir. The tag numbers, the release time, and the fish size were noted before releasing the tagged fish were released. Fishermen who caught the tagged fish were advised to report the fish tag number, time of catching, and fish size. The results showed that the Pangasianodon hypophthalmus could moved as far as $200 \mathrm{~m}$ to $15 \mathrm{~km}$ in 3-176 days. In the wet season most of the catfish moved far into the inlet Wiroko and Keduang, and some to the inlet Wuryantoro. Pangasianodon hypophthalmusin Gajah Mungkur Reservoir had growth equation of Lt=99(1-e$\left.{ }^{0.762(t-0.15)}\right)$, with the growth coeficient $(K)=0.762 /$ year, $t 0=0.15$ year, infinity length $(L \infty)=99 \mathrm{~cm}$. Water diversion of Keduang river, one of Gajah Mungkur inlets, did not fully dried the River during dry season and affected striped catfish movement and growth.
\end{abstract}

\section{KEYWORDS: $\quad$ Movement pattern, growth, striped fish, Pangasianodon hypophthalmus, reservoir}

\section{INTRODUCTION}

Movement is an essential mechanism by which mobile animals acquire the resources necessary for the successful completion of their life-cycles. It also plays a crucial role in how animals are distributed across the landscape and the persistence of populations and species. Regardless of how little or how far an animal moves, the purpose (e.g., foraging, reproduction, growth, refuge) and intensity (e.g., short, long, energetic, attenuated) of that animal's movement is intricately related to how its life history requirements change daily and/or seasonally (Hoffman \& Dunham, 2007). According to Halls \& Johns (2013), Pangasianodon hypophthalmus (synonym: Pangasius hypophthalmus) is a highly migratory riverine fish species that undertakes long-distance migrations over several hundred kilometres between upstream refuge and spawning habitats and downstream feeding and nursery habitats.

Gajah Mungkur, constructed in 1981 and located in Wonogiri Regency CentralJava with its surface area of 8,800 ha. Since the introduction of stipped catcfish in recent years, the production of this fish has reach 384 tonnes that approximately $40.04 \%$ of the total catch production of Gajah Mungkur researvoir after mossambicus tilapia (Dinas Peternakan, Perikanan dan Kelautan Kabupaten Wonogiri, 2010). Therefore information on movemement pattern and growth of the catfish in Gajah Mungkur is important to know. Diversion of Keduang river water, one of the inlets of Gajah Mungkur reservoir, to reduce Gajah Mungkur sedimentation in $2009 / 2010$, could influence the success of spawning and recruitment of striped fish. Taking into account that Keduang river is one of spawning of this fish. Gingerich \& Hanna (2006) reported that river water diversion is result in decreasing in stream flow and it may cause a continuous decrease of habitat for all species. For diverted conditions, the habitats at the majority of the studied stream sites were observed have only 27 to 57 percent from its original habitat. Restoring even a small amount of water to a diverted stream can have a significant effect on the amount of habitat available. For example, restoring 10 percent of the median baseflow to a stream that is dry owing to diversion would provide about 40 percent of the expected natural habitat.

Study on the movement and growth of small-sized striped catfish in Gajah Mungkur reservoir have been done by Purnomo et al. (2003). While studies on the effect of water diversion of Keduang River to striped catfish movement pattern and growth of the larger size 
(brooder candidate) specially in reserve area located around aquafarm fish floating net cages have not been recorded yet. According to Utomo et al. (2011), area located around Aquafarm fish floating net cages is functioning as striped catfish broodstock reserve at Gajah Mungkur. This area play a role as feeding area of this fish due to the abundance of foods resources escaping from floating net cages, no fishing activities and the water depth around 16 wchich support striped catfish life and growth.

Due to this fact, study in order to know the movement pattern and growth of large size striped catfish in Gajah Mungkur reservoir was conducted in 2011. The data and information obtained from this study will be used as component for fisheries

management and fish resources conservation in Gajah Mungkur Reservoir.

\section{MATERIALS AND METHODS}

Field works on striped catfish movement pattern and growth were carried out in Gajah Mungkur Reservoir, Wonogiri Regency, Central Java from March to December 2011 (Figure 1). Information on striped catfish movement patterns and growth were collected by using a tagging experiment. Prior tagging people around the reservoir were socialized about the objective of the study and the liability of fishermen if they catch the tagged fish (Appendix 1).

\section{Tagging Methods}

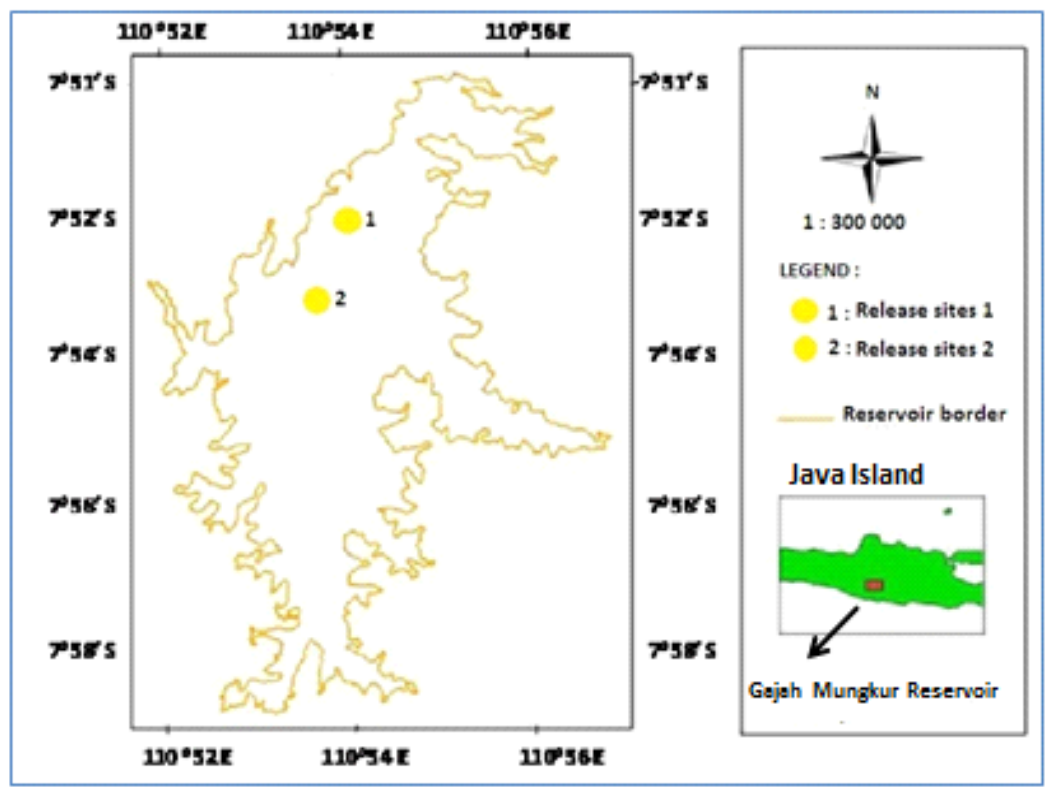

Figure 1. Map of released location.

Note Figure 1: Released 1 = Reserve area, around Aquafarm floating net cages Released 2 = Middle of reservoir, west of inlet Wiroko

A total of 868 striped catfish was collected from fishers which caught them from fish reserve area that, located around aquafarm fish floating net cages in Gajah Mungkur reservoir. Only healthy fish were tagged by inserting PDS-tags under dorsal fins of large fish (more than $2 \mathrm{~kg} /$ fish) (Figure 1.) and T-Bar tags for small fish(less than $2 \mathrm{~kg} / \mathrm{fish}$ ) (Hoggarth, 1994).Some information such as the number, fork length and total weight of tagged fishes; place, geographical position (GPS), and date of fish released were recorded. Tagged fishes were released in area of Aquafarm fish floating net cages. Fish were released in three phases. The first phase realease was in March as much as 200 individuals fish with a length of between 37 to $68 \mathrm{~cm}$ and weight of $600-5,000$ grams. The second release phase was in June as much as
200 individual fish, with a length from 40 to $63.5 \mathrm{~cm}$ and weight 960 to 3,400 grams. The third release phase was in September as much as 468 individuals fish, with a length of 18 to $35.5 \mathrm{~cm}$ and weight of 100 to 620 gram.

\section{Recapture of Tagged Fishes}

Information on the tagged fishes caught by the fishermen was obtained monthly. Fishermen caught the tagged fish, submitted the recapture data to either the head of fishermen group, to Fisheries Services of Wonogiri Regency or to the research team during the sampling time (Appendix 1). Those fishermen were rewarded to the T-shirtif their fish recorded was complete. 


\section{Growth Analysis}

Growth of the recapture tagged fishes were analyzed with Von Bertalanffy equation (Pauly,1984);

$L t=L \infty\left(1-e^{-k(t-t o)}\right)$

where $\mathrm{Lt}=$ length of fish at time $\mathrm{t}(\mathrm{cm})$,

$L \infty=$ Length of infinity $(\mathrm{cm})$,

$\mathrm{K}=$ growth coefficient,

$\mathrm{t}_{0}=$ Age at the length of $0 \mathrm{~cm}$.

Fish tag experiment gave the value of ÄL (an increment size during release and recaptured). Growth parameters: Length of infinity $(L)$ and growth coefficient $(K)$ were obtainet from linier: $L / t=a+$ b.L' (Gulland \& Holt after Spare \& Venema, 1992), where $L^{\prime}=$ the average of length increment between released and recaptured period; growth coefficient (K) $=-b$, and $L_{\infty}=-a / b$. Estimation of $t_{0}$ was calculated based on empirical equations of Pauly (1984): Log $\left(-t_{0}\right)=-0.3922-0.2752 \log L_{\infty}-1.038$ Log K. Length and weight relationships was analyzed based on Carlander equation after Effendi (1997): $\mathrm{W}=\mathrm{a} \mathrm{L}^{\mathrm{b}}$, where $W=$ weight $($ Gram) dan $L=$ length $(\mathrm{Cm})$. Simulation graph of weight growth (W) was made by entering the value of $L_{t}$ obtained from the Von Bertalanffy equation.

\section{RESULTS AND DISCUSSION Results}

\section{Fish Movement Patterns}

The first 13 recaptured tagged fish was recorded on July. The total number of recaptured tagged fishes until end of November were 34 fishes or $4 \%$ of the total released tagged fishes. Within 13-176 days, the distance of striped catfish movement from their the release site were in the range of $200 \mathrm{~m}$ to $15 \mathrm{~km}$. Generaly, in wet season most of striped catfish moved far to Wiroko and Keduang inlet, and some to the Wuryantoro inlet (Figure 2 and Appendix 2). Striped catfish which released around Aquafarm floating net cages moved to the northeast toward Keduang inlet, to the southeast towards Wiroko inlet and to the southwest toward Wuryantoro inlet. This phenomenon was also recorded for the striped catfish released in the middle of the reservoir (west of inlet wiroko). Most of the released striped catfish in this site moved to the west toward Wuryantoro inlet and to the east toward Wiroko inlet.

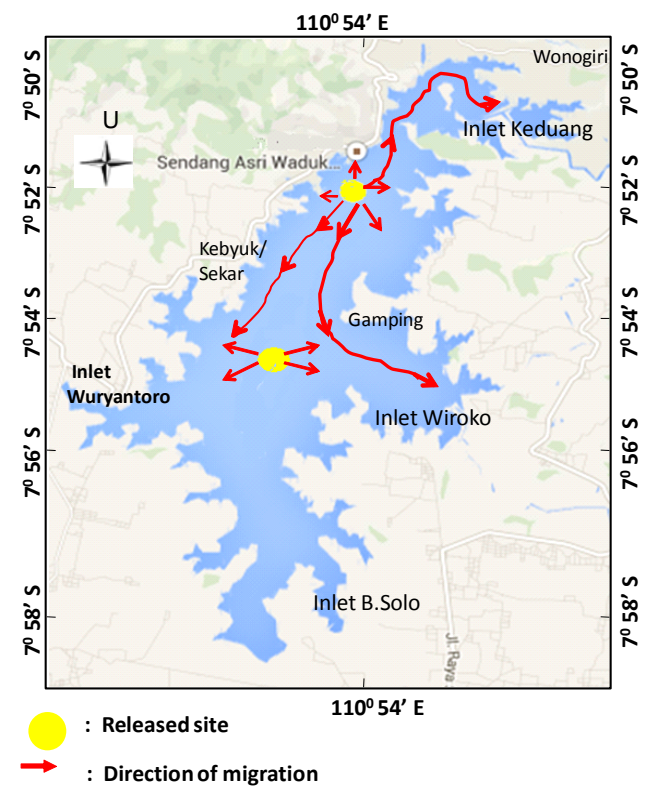

Figure 2. Striped catfish movement pattern map of in Gajah Mungkur Reservoir.

Tagged (marked) striped catfish were often caught by fishermen in Gamping/Nguntoronadi before reaching inlet Wirorko and in Kebyuk/Sekar before reaching Wuryantoro inlet. Both Gamping/ Nguntoronadi and Kebyuk/Sekar were movement path of striped catfish in Gajah Mungkur.

In wet season (November to February), both males and females of striped catfish that recorded in Gajah
Mungkur inlet (Keduang, Wiroko \& Wuryantoro) were at mature stage (ripe and spent) (Appendix 3). Whereas in dry season (June-September) none of tagged striped catfish were caught in most of Gajah Mungkur inlets. Fishing activities of striped catfish during dry season were inside of the reservoir but none of striped catfish caught in mature stage. 


\section{Individual Striped Catfish Growth}

Out of 34 recaptured tagged fish, only 28 of them had complete information that can be used for further growth analysis (Appendix 4). Regression equation of the length recapture tagged data was $(\Delta \mathrm{L} / \Delta \mathrm{T})=$ $6.343-0.0635\left(L^{\prime}\right)$. Based on that equations, it was found that growth coefficient $(\mathrm{K})$ was 0.0635 per month or 0.762 / year, asymptotic length (Lo) was $99 \mathrm{~cm}$, and the age of the fish at the time length $0\left(\mathrm{t}_{0}\right)$ was 1.8 months or $-0,15$ years.

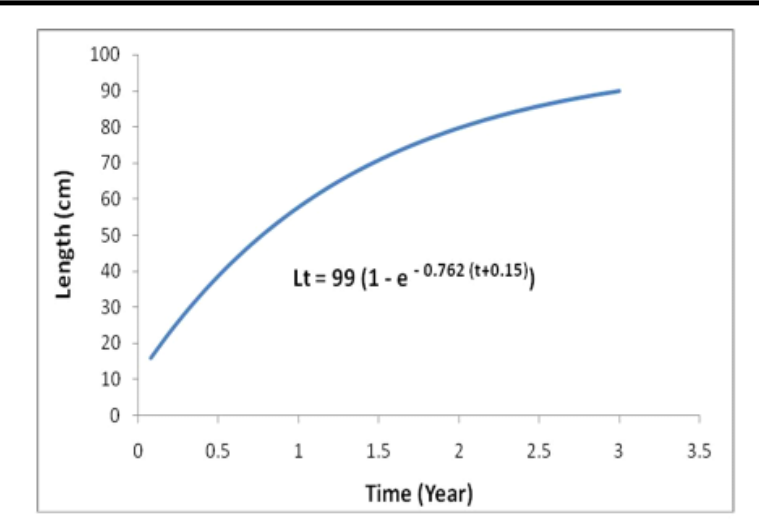

Figure 3. Length growth simulation of striped catfish
Based on the growth parameters $\left(\mathrm{L}_{\infty}, \mathrm{K}\right.$ and $\left.\mathrm{t}_{0}\right)$ and changing the value of " $\mathrm{t}$ " as the independent variable, Vont Bertalanffy growth curve length was found, $\mathrm{Lt}=99\left(1-\mathrm{e}^{-0.762(\mathrm{t}+0.15)}\right)$ (Table 1 and Figure 3 ). Analysis on the length and weight relationship of striped catfish obtained the equation of $W=0,005$ $\mathrm{L}^{3,192}$. Length growth chart in Figure 3 was converted into weight growth as shown in Table 1 and Figure 4 .

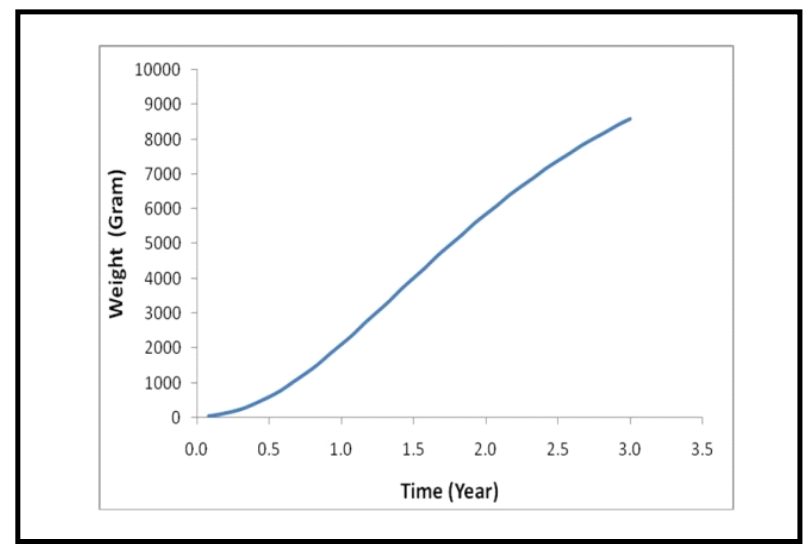

Figur 4. Weight growth simulation of striped catfish

Table 1. Length and weight growth simulation of striped catfish

\begin{tabular}{crrrrr}
\hline $\begin{array}{c}\text { Age } \\
\text { (month) }\end{array}$ & Length $(\mathbf{c m})$ & $\begin{array}{l}\text { Weight } \\
\text { (gram) }\end{array}$ & Age (month) & Length $(\mathbf{c m})$ & $\begin{array}{c}\text { Weight } \\
\text { (gram) }\end{array}$ \\
\hline 1 & 16.1 & 35.8 & 25 & 80.9 & $6,165.2$ \\
2 & 21.2 & 86 & 26 & 82.1 & $6,439.3$ \\
3 & 26.0 & 164.5 & 27 & 83.1 & 6,704 \\
4 & 30.5 & 273.5 & 28 & 84.1 & $6,959.2$ \\
5 & 34.7 & 413.3 & 29 & 85.0 & $7,204.7$ \\
6 & 38.7 & 583.3 & 30 & 85.9 & $7,440.4$ \\
7 & 42.4 & 781.5 & 31 & 86.7 & $7,666.4$ \\
8 & 45.9 & $1,005.6$ & 32 & 87.4 & $7,882.7$ \\
9 & 49.1 & $1,252.8$ & 33 & 88.1 & $8,089.5$ \\
10 & 52.2 & 1,520 & 34 & 88.8 & 8,287 \\
11 & 55.1 & $1,804.2$ & 35 & 89.4 & $8,475.2$ \\
12 & 57.8 & $2,102.2$ & 36 & 90.0 & $8,654.6$ \\
13 & 60.3 & 2,411 & 37 & 90.6 & $8,825.2$ \\
14 & 62.7 & 2,728 & 38 & 91.1 & $8,987.5$ \\
15 & 64.9 & $3,050.5$ & 39 & 91.6 & $9,141.6$ \\
16 & 67.0 & 3,376 & 40 & 92.0 & $9,287.9$ \\
17 & 69.0 & $3,702.6$ & 41 & 92.5 & $9,426.6$ \\
18 & 70.8 & $4,028.1$ & 42 & 92.9 & $9,558.1$ \\
19 & 72.6 & $4,351.1$ & 43 & 93.2 & $9,682.6$ \\
20 & 74.2 & $4,669.9$ & 44 & 93.6 & $9,800.5$ \\
21 & 75.7 & $4,983.4$ & 45 & 93.9 & 9,912 \\
22 & 77.2 & $5,290.5$ & 46 & 94.2 & $10,017.5$ \\
23 & 78.5 & $5,590.3$ & 47 & 94.5 & $10,117.2$ \\
24 & 79.8 & 5,882 & 48 & 94.8 & $10,211.3$ \\
\hline
\end{tabular}




\section{Discussion}

\section{Movement Patterns of Striped Catfish}

Total fishes recaptured during the study in the Gajah Mungkur reservoir (8,800 ha) was 4\%. Other studies on fish tagging experiments of striped catfish (Pangasianodon hypophthalmus) in Kedung Ombo reservoir (4,400 ha) total recapterd much as $10 \%$ (Aida et al., 2013), tagging experiment of fish carp white lady (Thynnichthys thynnoides) in Empangau Lake (125 ha) total fishes recaptured much as $24 \%$ (Utomo, 2009). Based on the above information, there are indications that the wider of water area then the possibility of fishes recaptured caught is getting smaller.

The occurance of matured striped catfish males and females in most of Gajah Mungkur inlets is an indicator that this fish move to the inlets either for seeking the refuge area or for spawning. During spawning time the matured striped catfish would move to fast flowing water area which were found and recorded in most of Gajah Mungkur inlets. According to Gustiano \& Pouyaud (2005), the original habitat of striped catfish was in the river, and often found in deep water. The matured striped cat fish which ready to spawn were often found in the upstream river with characteristic of fast flowing water. While Kottelat et al. (1993) reported that matured striped catfishare often found in the upstream river. After spawning, larvae drift to downstream, clinging to rocks and riparian vegetation. This was supported by the occurance of matured striped catfish during the wet season. As s peak spawning season. The amount of the wet fall during the wet season was in the range of $288.5-460.5 \mathrm{~mm} / \mathrm{month}$ and while in dry season was $42-194 \mathrm{~mm} / \mathrm{month}$ (Direktorat Pengelolaan Bengawan Solo, 2010).

Large striped catfish which mostly larger than 50 $\mathrm{cm}$ or more than 1,500 gram (appendix 2 and 4) were able to migrate in along distance to the Wiroko and Keduang inlet. Studies conducated by Utomo et al. (2005) and Dharyati et al. (2010) also found that during wet season (November - January) striped catfish caught in Keduang inlet were larger than $2 \mathrm{~kg}$ and ready to spawn. According to Legendre et al. (1999) after the Kristanto et al. (2005), the gonad of pond cultured striped catfish will mature after 19 month, and spawn during the wet season from October to April. Furthermor, Rahardhianto et al. (2012) repoted that in its natural habitat, striped catfish spawn in the rainy season with the larvae and juvenile were found from March to May.
Far movement of tagged striped catfish released around Aquafarm floating net cages during the rainy season to the spawning areas in Gajah Mungkur inlets showed that fish reserve around Aquafarm floating net cages had significance role for the availability of striped catfish, could contribute fish production outside the reserve area, and to increase fisheries production in Gajah Mungkur Reservoir. According to Utomo et al. (2001) a proper functioned of fish reserve area could increase fish production to others water body. In addition, no fishing ativities and the present a lot of feed (pellet and fish feces) that escaped from floating fish net cages supported for the occurence young striped catfish in Aquafarm floating net cages areas. Dharyati et al. (2009) mentioned that the amount of feed waste escaped from the floating net cages in Gajah Mungkur Reservoir was 470 tonnes/year.

Diversion of Keduang River to decrease the sedimentation of Gajah Mungkur reservoir did not effect much to water depth and fish movement. During dry season, Keduang inlet and other inlet (wiroko) were still inundated by the shallow water. This two Gajah Mungkur inlets inhabited by aquatic plants dominated by Mimmosa pigra, locally called kayu duri. This finding was similar with Ali (2013) who found small size striped catfish $(5-7 \mathrm{~cm})$ in fishermen catch near the Wiroko inlet. These aquatic plants served as feeding, nursery and spawning ground of the fish. According to Utomo \& Asyari (1999), aquatic plants such as swamp forests had important role for fish resources. Catfish (Pangasius nasutus), known locally as Seladang in Kapuas River feed on fruit and seed fallen from swamp forest.

\section{Individual Growth of striped catfish}

Growth parameters obtained in this study was a little bit different from Purnomo et al. (2003) with K value of $0.95 /$ year and $L_{\infty}$ value of $122 \mathrm{~cm}$. High K and $L \infty$ value reported in Purnomo et al. (2003) more related to the small fish size used which, $22 \mathrm{~g} /$ fish. While in this study the fish size used was in the range of $100-5.000 \mathrm{~g} /$ fish. Large adult fish grow more slowly than small younger fish, yet for adult fish most energy is used for reproductive development and maintenance of old organs (Mantel,1983 in Utomo, 2005).

Striped catfish in Gajah Mungkur reservoir have a rapid growth, even faster than fish culture intensively.According to Kristanto et al. (2005) growth of striped catfish juvenile cultured in ponds for 19 months was $2,249 \mathrm{~g} / \mathrm{fish}$, whereas in this study they could reach 4,351g/fish (Table 1 and Figure 4). According to Asyari et al. (1997) growth of striped 
catfish juvenile cultured in floating cages in the Musi River for 12 months was 926 gram/fish, whereas in this study can reach 2,102 g/fish (Table 1 and Figure 4). Rapid growth of striped catfish in Gajah Mungkur Reservoir is related to the present of food (pellets) and the abudance fish feces escaped from the floating net cages, as well as the abundance of detritus and plankton (Dharyati et al., 2009; Utomo et al., 2011). Similar phenomenom was also recorded by Purnomo et al. (2003); striped catfish can grow well in Gajah Mungkur Reservoir, due to a lot of suitable natural foods such as plankton and detritus. In addition, faster growth of striped catfish in Gajah Mungkur may relate to the presence of fish habitat protection (fish reserve) around Aquafarm floating net cages and habitat condition of the nursery ground in inlet Wiroko and inlet Keduang Gajah Mungkur Reservoir suitable for the survival of striped catfish (Aida et al., 2011).

\section{CONCLUSION}

Water diversion of Keduang River, one of Gajah Mungkur inlets, did not fully dried the river during dry season and affected striped catfish movement and growth. In wet season, striped catfish move as far as $15 \mathrm{~km}$ away from the release area of reserve area around Aquafarm floating net cages to Keduang and Wiroko inlets for seeking refuge and spawning area. Reserve area around Aquafarm floating net cages play an important role for sustainable fish production of Gajah Mungkur reservoir.

\section{ACKNOWLEDGEMENTS}

This manuscript is a part of potency and utilization of Gajah Mungkur Reservoir funded by Indonesia government budget in 2010. We would like to thank the Head of Research Institute for inland fisheries Palembang for supporting this research, Head of Fisheries and Marine Departement Wonogiri, researchers and technicians who have assstance in the implementation of this research.

\section{REFERENCES}

Aida, S.N., A.D. Utomo \& M. Ali. 2011. Bioekologi dan potensi sumberdaya perikanan di Waduk Gajah Mungkur. Laptek Th 2011. Balai Penelitian Perikanan Perairan Umum Palembang. 140 hal.

Aida, SN, A.D. Utomo, T. Hidayah, M. Ali \& R.D. Mentari, 2013. Percobaan penebaran ikan Patin (Pangasianodon hypopthalmus) di waduk Kedung Ombo. Laptek Th. 2013. Balai Penelitian Perikanan Perairan Umum Palembang. 120 hal.
Ali, M. 2013. Komposisi dan kelimpahan ichtioplankton serta hubungannya dengan parameter lingkungan di Waduk Gajah Mungkur. Tesis. Pascasarjana Ilmu Lingkungan Universitas Sriwijaya. Palembang. 60 hal.

Asyari, Z. Arifin \& A.D. Utomo. 1977. Pembesaran Ikan Patin (Pangasius pangasius $H B$ ) dalam sangkar di Sungai Musi. Jurnal Penelitian Perikanan Indonesia. Vol.3(2): 83-90.

Dharyati, E., A.D. Utomo, S. Adjie, Asyari, S.N. Aida, D. Wijaya, F. Supriadi, R. Ridho \& E. Saleh. 2009. Pendugaan stratifikasi tropogenic layer, carrying capacity beban pakan dari KJA di Waduk Kedung Ombo dan Gajah Mungkur, Jawa Tengah. Laporan Akhir Tahun. Balai Penelitian Perikanan Perairan Umum Palembang. 160 hal

Dharyati, E., A.D. Utomo, S. Adjie, Asyari, S.N. Aida, D. Wijaya, F. Supriadi, R. Ridho \& E. Saleh. 2010. Bioekologi dan potensi sumberdaya perikanan di Waduk Gajah Mungkur dan Kedung Ombo, Jawa Tengah. Laporan Akhir Tahun. Balai Penelitian Perikanan Perairan Umum Palembang. 165 hal

Dinas Peternakan, Perikanan dan Kelautan Kabupaten Wonogiri. 2010. Pengelolaan usaha perikanan di Waduk Gajah Mungkur Wonogiri. 10 hal.

Direktorat Pengelolaan Bengawan Solo 2010. Rencana Operasional Waduk Gajah Mungkur. Jasa Tirta I. Solo-Surakarta. 18 hal.

Effendie, M.I. 1997. Biologi Perikanan. Yayasan Pustaka Nusatama, Yogyakarta.163 hal.

Gingerich, S \& S. Hanna. 2006. Effects of surfacewater diversion on native fish habitat in northeast Maui. U.S. Department of the Interior, U.S. Geological Survey Office of Communication119 National Center Reston, VA.

Gustiano \& L. Pouyaud. 2005. Riverine Catfishes of Kalimantan, Pangasidae: diagnosis, distribution, and ecology. Indonesian Fisheries Research Journal. Vol.11: p. 59-66.

Halls, A.S \& M. Johns. 2013. Assessment of the vulnerability of the Mekong Delta Pangasius catfish industry to development and climate change in the Lower Mekong Basin. Report prepared for the Sustainable Fisheries Partnership, January 2013. $95 \mathrm{pp}$. 
Hoffman, R \& J. Dunham. 2007. Fish-movement ecology in high-gradient headwater stream: Its relevance to fish passage restoration through stream culvert barriers. U.S. Geological survey, OFR 2007-1140. 40 pp.

Hoggarth, D. 1994. Survey methodologies. Fisheries dynamics of modified floodplains in Southern Asia. MRAG, London. 46 pp.

Kottelat, M., J.A. Whitten, N. Kartikasari \& S. Wiryatmojo. 1993. Freshwater Fishes of Western Indonesia and Sulawesi, Periplus Ed. And EMDI Project Indonesia. $221 \mathrm{pp}$.

Kristanto, A.H., J. Slembrouck \& M. Legendre. 2005. First sexual maturation and breeding cycle of Pangasius hypophthalmus reared in pond. Indonesian Fisheries Research Journal. Vol.11:p. 53-57.

Pauly, D. 1984. Some simple methods for the assessment of tropical fish stock. ICLARM. Makati, Metro manila Philiphines: $52 \mathrm{pp}$.

Purnomo, K., E.S. Kartamihardja \& S. Koeshendradjana. 2003. Pertumbuhan, mortalitas, dan kebiasaan makanan ikan Patin (Pangasius hyphophthalmus) introduksi di Waduk Gajah Mungkur. Jurnal Penelitian Perikanan Indonesia. Edisi Sumberdaya dan Penangkapan. Vol.9 (3): 13-21.

Rahardhianto, A., M. Abdulgani \& N. Trisyan. 2012. Pengaruh konsentrasi larutan madu dalam $\mathrm{NaCl}$ fisiologis terhadap viabilitas dan motilitas spermatozoa ikan Patin (Pangasius pangasius) selama masa penyimpanan. Jurnal Sain dan Seni ITS. Vol.1 (1): 58-63.

Spare, P \& S.C. Venema. 1992. Introduction to Tropical Fish Stock Assessment. FAO-DANIDA, Rome. 306 (1): 375 pp.
Utomo, A.D \& Asyari. 1999. Peran ekosistem hutan rawa air tawar bagi kelestarian sumberdaya perikanan di sungai Kapuas Kalimantan Barat. Jurnal Penelitian Perikanan Indonesia. Edisi Sumberdaya dan Penangkapan.Vol.5 (3): 1-13.

Utomo, A.D., Asyari \& S. Nurdawati. 2001. Peranan suaka perikanan dalam peningkatan produksi dan pelestarian sumberdaya ikan di perairan umum. Jurnal Penelitian Perikanan Indonesia. Edisi Sumberdaya dan Penangkapan.Vol.7 (1): 1-9.

Utomo, A.D. 2005. Pertumbuhan dan biologi reproduksi udang galah (Macrobrachium rosenbergii) di sungai Lempuing Sumatera Selatan. Jurnal Penelitian Perikanan Indonesia. Edisi Sumberdaya dan Penangkapan. Vol.8 (1): 15-26.

Utomo, A.D., S. Adjie, N. Muflikah \& A. Wibowo. 2005. Distribusi jenis ikan dan kualitas perairan di Bengawan solo. Jurnal Penelitian Perikanan Indonesia. Vol. 12 (2): 1-12.

Utomo, A.D. 2009. Ruaya dan pertumbuhan ikan Entukan (Thynnichthys thynnoides) di danau Empangau Kalimantan Barat. Prosiding Forum Perairan Umum Indonesia ke VI, Palembang 18 Nopember 2009. BP3U Palembang. Hal 47-55.

Utomo, A.D., M.R. Ridho \& D.D.A. Putranto, 2011. Keanekaragaman plankton dan tingkat kesuburan perairan di Waduk Gajah Mungkur. BAWAL, Vol.3 (6): 415-422.

Utomo, A.D., S.N. Aida \& Z. Fahmi, 2011. Pendugaan stok ikan di Waduk Gajah Mungkur. Prosiding Forum Perairan Umum Indonesia ke VIII, Palembang 26 - 27 September 2011. BP3U Palembang. Hal 241- 251. 
Appendix 1. The explanation of how to noting and sending a note of marked fish recaptured by fishermen.

Whoever catches tagged striped catfish in Gajah Mungkur please noting the following required information:

\begin{tabular}{|l|l|l|}
\hline Tag number: & Date: & Fork Length $(\mathrm{Cm}):$ \\
\hline \hline Caught Location: & Fishing Gear: & $\begin{array}{l}\text { Name and Address of } \\
\text { fishermen: }\end{array}$ \\
\hline
\end{tabular}

Remove the tag which attached at the body of the fish, then the tag and notes submited to Fisheries Department officer or chairman of a group of fishermen or research team at the moment they come to Gajah Mungkur Reservoir. Each delivery complete note of mark/tag are rewarded in the form of a T-shirt or money worth Rp.75,000 (Seventy Five Thousand). The fish do not need to be submitted, only the tag and notes shall be submitted.

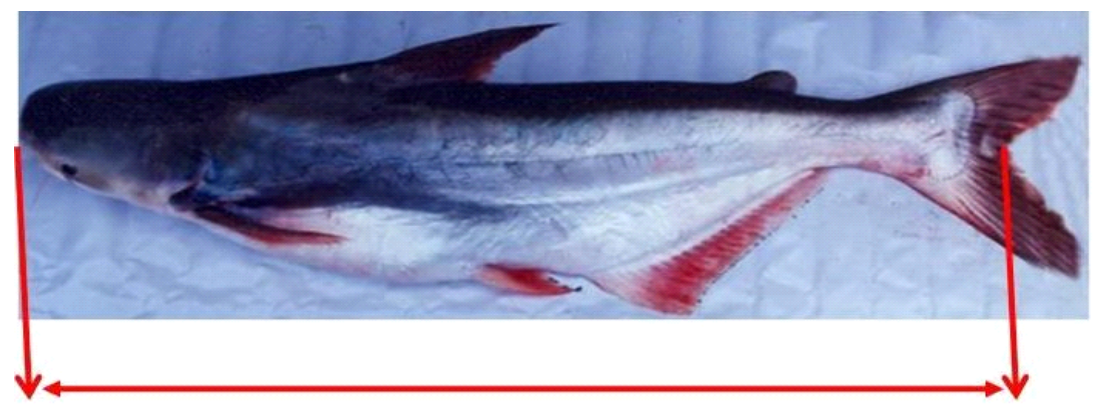

Fork Length $(\mathrm{Cm})$

Appendix 2. The movement pattern of $P$. hypopthalmus at Gajah Mungkur Reservoir

\begin{tabular}{|c|c|c|c|c|c|}
\hline \multirow{2}{*}{ No } & \multirow[b]{2}{*}{ Code. Tags } & \multicolumn{2}{|r|}{ Location } & \multirow[b]{2}{*}{ Distance } & \multirow{2}{*}{$\begin{array}{l}\text { Days } \\
(\Delta \mathrm{T})\end{array}$} \\
\hline & & Release & Recapture & & \\
\hline \multicolumn{6}{|c|}{$\begin{array}{l}\text { A.Released } 1 \\
\text { (15 March 2011) }\end{array}$} \\
\hline 1 & PDS 00111 & KJA Aquafarm & Northeast of released site. & $200 \mathrm{~m}$ & 13 \\
\hline 2 & PDS 00178 & KJA Aquafarm & Southwest of released site. & $200 \mathrm{~m}$ & 18 \\
\hline 3 & PDS 00122 & KJA Aquafarm & $\begin{array}{l}\text { Northeast of released. } \\
\text { Direction to inlet Keduang }\end{array}$ & $2 \mathrm{~km}$ & 23 \\
\hline 4 & PDS 00172 & KJA Aquafarm & $\begin{array}{l}\text { Northeast of released. } \\
\text { Direction to inlet Keduang } \\
\text { Gamping. Sotheast of }\end{array}$ & $2 \mathrm{~km}$ & 28 \\
\hline 5 & PDS 00083 & KJA Aquafarm & $\begin{array}{l}\text { released .Direction to inlet } \\
\text { Wiroko }\end{array}$ & $15 \mathrm{~km}$ & 52 \\
\hline 6 & PDS 00137 & KJA Aquafarm & $\begin{array}{l}\text { Gamping. Sotheast of } \\
\text { released. Direction to inlet } \\
\text { Wiroko }\end{array}$ & $15 \mathrm{~km}$ & 78 \\
\hline 7 & PDS 00153 & KJA Aquafarm & $\begin{array}{l}\text { East of released. Direction } \\
\text { to inlet of Keduang }\end{array}$ & $15 \mathrm{~km}$ & 79 \\
\hline 8 & PDS 00182 & KJA Aquafarm & $\begin{array}{l}\text { Gamping. Sotheast of } \\
\text { released. Direction to inlet } \\
\text { Wiroko }\end{array}$ & $7 \mathrm{~km}$ & 80 \\
\hline 9 & PDS 00046 & KJA Aquafarm & $\begin{array}{l}\text { Kebyuk. Southwest of } \\
\text { released. Direction to inlet } \\
\text { Wuryantro }\end{array}$ & $7 \mathrm{~km}$ & 115 \\
\hline 10 & PDS 00192 & KJA Aquafarm & $\begin{array}{l}\text { Gamping. Sotheast of } \\
\text { released. Direction to inlet } \\
\text { Wiroko }\end{array}$ & $7 \mathrm{~km}$ & 176 \\
\hline
\end{tabular}


Appendix 2. Continution

\begin{tabular}{|c|c|c|c|c|c|}
\hline \multicolumn{6}{|c|}{$\begin{array}{l}\text { B.Released } 2 \\
\text { (15 June 2011) }\end{array}$} \\
\hline 11 & PDS 00333 & KJA Aquafarm & $\begin{array}{l}\text { Kebyuk. Southwest of } \\
\text { released. Direction to inlet } \\
\text { Wuryantro }\end{array}$ & $10 \mathrm{~km}$ & 18 \\
\hline 12 & PDS 00236 & KJA Aquafarm & $\begin{array}{l}\text { Southeast of released site. } \\
\text { Direction to inlet Wiroko }\end{array}$ & $500 \mathrm{~m}$ & 18 \\
\hline 13 & PDS 00323 & KJA Aquafarm & $\begin{array}{l}\text { Southeast of released site. } \\
\text { Direction to inlet Wiroko }\end{array}$ & $500 \mathrm{~m}$ & 26 \\
\hline 14 & PDS 00367 & KJA Aquafarm & $\begin{array}{l}\text { Southeast of released site. } \\
\text { Direction to inlet Wiroko }\end{array}$ & $500 \mathrm{~m}$ & 26 \\
\hline 15 & PDS 00395 & KJA Aquafarm & $\begin{array}{l}\text { Northeast of released site. } \\
\text { Direction to inlet Keduang. }\end{array}$ & $500 \mathrm{~m}$ & 31 \\
\hline \multicolumn{6}{|c|}{$\begin{array}{l}\text { A.Released } 1 \\
\text { (19 September } \\
2011)\end{array}$} \\
\hline 16 & PDS 00037 & $\begin{array}{l}\text { Middle of } \\
\text { Reservoir }\end{array}$ & West of released site & $300 \mathrm{~m}$ & 3 \\
\hline 17 & PDS 00114 & $\begin{array}{l}\text { Middle of } \\
\text { Reservoir }\end{array}$ & West of released site. & $300 \mathrm{~m}$ & 3 \\
\hline 18 & 029 & $\begin{array}{l}\text { Middle of } \\
\text { Reservoir }\end{array}$ & West of released site. & $300 \mathrm{~m}$ & 5 \\
\hline 19 & PDS 0436 & KJA Aquafarm & Southwest of released site. & $400 \mathrm{~m}$ & 14 \\
\hline 20 & PDS 0404 & KJA Aquafarm & Southwest of released site & $200 \mathrm{~m}$ & 6 \\
\hline 21 & 389 & $\begin{array}{l}\text { Middle of } \\
\text { Reservoir }\end{array}$ & West of released site & $200 \mathrm{~m}$ & 8 \\
\hline 22 & 214 & KJA Aquafrm & $\begin{array}{l}\text { Kebyuk.Southwest of } \\
\text { released site. }\end{array}$ & $300 \mathrm{~m}$ & 12 \\
\hline 23 & 241 & KJA Aquafrm & $\begin{array}{l}\text { Inlet Wiroko. Southeast of } \\
\text { released site. }\end{array}$ & $15 \mathrm{~km}$ & 47 \\
\hline 24 & 376 & $\begin{array}{l}\text { Middle of } \\
\text { Reservoir }\end{array}$ & $\begin{array}{l}\text { Gamping. East of released } \\
\text { site. Direktions to inlet } \\
\text { Wiroko }\end{array}$ & $400 \mathrm{~m}$ & 38 \\
\hline 25 & 449 & $\begin{array}{l}\text { Middle of } \\
\text { Reservoir }\end{array}$ & $\begin{array}{l}\text { Kebyuk. West of released } \\
\text { site }\end{array}$ & $200 \mathrm{~m}$ & 15 \\
\hline 26 & 334 & $\begin{array}{l}\text { Middle of } \\
\text { Reservoir }\end{array}$ & $\begin{array}{l}\text { Gamping. East of released } \\
\text { site. Direktions to inlet } \\
\text { Wiroko }\end{array}$ & $400 \mathrm{~m}$ & 16 \\
\hline 27 & 358 & $\begin{array}{l}\text { Middle of } \\
\text { Reservoir }\end{array}$ & $\begin{array}{l}\text { Kebyuk..West of released } \\
\text { site }\end{array}$ & $300 \mathrm{~m}$ & 25 \\
\hline 28 & 281 & $\begin{array}{l}\text { Middle of } \\
\text { Reservoir }\end{array}$ & $\begin{array}{l}\text { Gamping. East of released } \\
\text { site }\end{array}$ & $300 \mathrm{~m}$ & 13 \\
\hline 29 & 403 & $\begin{array}{l}\text { Middle of } \\
\text { Reservoir }\end{array}$ & Sekar. West of released site & $300 \mathrm{~m}$ & 18 \\
\hline 30 & 038 & $\begin{array}{l}\text { Middle of } \\
\text { Reservoir }\end{array}$ & $\begin{array}{l}\text { Gamping. East of released } \\
\text { site. Direktions to inlet } \\
\text { Wiroko }\end{array}$ & $400 \mathrm{~m}$ & 17 \\
\hline 31 & 164 & KJA Aquafarm & $\begin{array}{l}\text { Northeast of released site. } \\
\text { Direction to inlet of Keduang }\end{array}$ & $500 \mathrm{~m}$ & 17 \\
\hline 32 & 221 & KJA Aquafarm & Northeast of released site. & $200 \mathrm{~m}$ & 7 \\
\hline 33 & 169 & KJA Aquafarm & $\begin{array}{l}\text { Kebyuk. Southwest of } \\
\text { released site }\end{array}$ & $200 \mathrm{~m}$ & 13 \\
\hline 34 & 217 & KJA Aquafarm & $\begin{array}{l}\text { Kebyuk.. Southwest of } \\
\text { released site }\end{array}$ & $200 \mathrm{~m}$ & 18 \\
\hline
\end{tabular}


Appendix 3. Gonade maturity stage of striped catfish (Pangasianodon hypophthalmus) in Gajah Mungkur Reservoir

I. In Wet Season (November- Februari)

\begin{tabular}{lrrrr}
\hline Gonade Maturity Stage & \multicolumn{2}{c}{ Inlet of River } & \multicolumn{2}{c}{ Inside of Reservoir } \\
\cline { 2 - 5 } & (indv.) & (\%) & (indv.) & (\%) \\
\hline A. Male & & & 4 & 11.4 \\
I.(immature) & 0 & 0 & 11 & 31.4 \\
II.(early maturing) & 0 & 0 & 2 & 5.7 \\
III.(late maturing) & 1 & 2.7 & 0 & 0 \\
IV.(ripe) & 9 & 24 & 0 & 0 \\
V.(spent) & 5 & 13 & & \\
B. Female & & & 3 & 8.6 \\
I.(immature) & & & 14 & 40 \\
II.(early maturing) & 0 & 0 & 1 & 0 \\
III.(late maturing) & 0 & 0 & 0 & 0 \\
IV.(ripe) & 1 & 2.7 & 0 & 100 \\
V.(spent) & 13 & 35 & 35 & \\
\hline
\end{tabular}

II.In Dry Season (June - September)

\begin{tabular}{|c|c|c|c|c|c|}
\hline \multirow[t]{3}{*}{ Gonade Maturity Stage } & \multicolumn{5}{|c|}{ Location } \\
\hline & \multicolumn{2}{|c|}{ Inlet of River } & & \multicolumn{2}{|c|}{ Inside of Reservoir } \\
\hline & (indv.) & $(\%)$ & & (indv.) & $(\%)$ \\
\hline \multicolumn{6}{|l|}{ A. Male } \\
\hline I.(immature) & & & - & 1 & 3.3 \\
\hline II.(early maturing) & & & - & 4 & 13.3 \\
\hline III.(late maturing) & & & - & 0 & 0 \\
\hline IV.(ripe) & & & - & 0 & 0 \\
\hline V.(spent) & & & - & 0 & 0 \\
\hline B. Female & & & - & & \\
\hline I.(immature) & & & - & 4 & 13.3 \\
\hline II.(early maturing) & & & - & 19 & 63.3 \\
\hline III.(late maturing) & & & - & 2 & 6.8 \\
\hline IV.(ripe) & & & - & 0 & 0 \\
\hline V.(spent) & & & - & 0 & 0 \\
\hline TOTAL & & & & 30 & 100 \\
\hline
\end{tabular}

Note Appendix 3:

$(-)=$ No fishing activity of striped catfish. 
Appendix 4. Increment size of striped catfish (Pangasionodon Hypopthalmus) after fish recaptured

\begin{tabular}{llrrrrrrr}
\hline No & No tags: & $\begin{array}{c}\mathrm{L} 1 \\
(\mathrm{~cm})\end{array}$ & $\begin{array}{c}\mathrm{L} 2 \\
(\mathrm{~cm})\end{array}$ & $\begin{array}{c}\Delta \mathrm{L} \\
(\mathrm{cm})\end{array}$ & $\begin{array}{c}\Delta \mathrm{t} \\
(\text { hari })\end{array}$ & $\begin{array}{c}\mathrm{L}^{\prime} \\
(\mathrm{cm})\end{array}$ & $\begin{array}{c}\Delta \mathrm{L} / \Delta \mathrm{T} \\
\mathrm{cm} / \text { Day }\end{array}$ & $\begin{array}{c}\Delta \mathrm{L} / \Delta \mathrm{T} \\
\mathrm{cm} / \text { Month }\end{array}$ \\
\hline 1 & PDS 00111 & 49 & 51 & 2 & 13 & 50.0 & 0.15 & 4.62 \\
2 & PDS 00178 & 48 & 52 & 4 & 18 & 50.0 & 0.22 & 6.67 \\
3 & PDS 00122 & 61 & 62 & 1 & 23 & 61.5 & 0.04 & 1.30 \\
4 & PDS 00172 & 44 & 48 & 4 & 28 & 46.0 & 0.14 & 4.29 \\
6 & PDS 00083 & 59 & 64 & 5 & 40 & 61.5 & 0.13 & 3.75 \\
7 & PDS 00137 & 56 & 62 & 6 & 78 & 59.0 & 0.08 & 2.31 \\
8 & PDS 00153 00182 & 44 & 52 & 8 & 79 & 48.0 & 0.10 & 3.04 \\
9 & PDS 00046 & 42 & 52 & 10 & 80 & 47.0 & 0.13 & 3.75 \\
10 & PDS 0192 & 53 & 63 & 10 & 115 & 58.0 & 0.09 & 2.61 \\
11 & PDS 00333 & 44 & 47 & 3 & 18 & 45.5 & 0.17 & 5.00 \\
12 & PDS 00236 & 59 & 62 & 3 & 26 & 60.5 & 0.12 & 3.46 \\
14 & PDS 00367 & 52 & 55 & 3 & 31 & 53.5 & 0.10 & 2.90 \\
15 & PDS 00395 & 48 & 55 & 7 & 80 & 51.5 & 0.09 & 2.63 \\
16 & 029 & 26 & 27 & 1 & 9 & 26.5 & 0.11 & 3.33 \\
17 & PDS 0436 & 51.5 & 55 & 3.5 & 47 & 53.3 & 0.07 & 2.23 \\
\hline
\end{tabular}




\section{Appendix 4. Continution}

\begin{tabular}{|c|c|c|c|c|c|c|c|c|}
\hline 18 & PDS 0404 & 58 & 61 & 3 & 38 & 59.5 & 0.08 & 2.37 \\
\hline 19 & 214 & 30.5 & 32 & 1.5 & 16 & 31.3 & 0.09 & 2.81 \\
\hline 20 & 241 & 21 & 26 & 5 & 25 & 23.5 & 0.20 & 6.00 \\
\hline 21 & 376 & 26.5 & 28 & 2 & 13 & 27.3 & 0.12 & 3.46 \\
\hline 22 & 449 & 26 & 28 & 2 & 16 & 27.0 & 0.13 & 3.75 \\
\hline 23 & 334 & 27 & 29 & 2 & 17 & 28.0 & 0.12 & 3.53 \\
\hline 24 & 281 & 25 & 27 & 2 & 13 & 26.0 & 0.15 & 4.62 \\
\hline 25 & 403 & 27 & 29 & 2 & 18 & 28.0 & 0.11 & 3.33 \\
\hline 26 & 38 & 27 & 28 & 1 & 17 & 27.5 & 0.06 & 1.76 \\
\hline 27 & 169 & 26 & 29 & 3 & 21 & 27.5 & 0.14 & 4.29 \\
\hline \multirow[t]{2}{*}{28} & 217 & 31.5 & 33 & 1.5 & 16 & 32.3 & 0.09 & 2.81 \\
\hline & & & & & & $(X)$ & & $(Y)$ \\
\hline \multicolumn{3}{|c|}{$\begin{array}{l}\mathrm{L} 1: \text { The size of fish when released } \\
\mathrm{L} 2: \text { The size of fish when recaptured } \\
\text { recaptured }\end{array}$} & & \multicolumn{5}{|c|}{$\begin{array}{l}\text { Difference in time when released and recaptured } \\
\text { Difference in size when released and when }\end{array}$} \\
\hline
\end{tabular}

